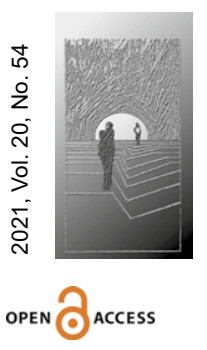

\title{
Prawodemia, czyli o rzeczywistości prawnej w dobie pandemii w Polsce
}

\section{STRESZCZENIE}

CEL NAUKOWY: Celem naukowym niniejszej publikacji jest opisanie i uzasadnienie istnienia zjawiska prawodemii w dobie pandemii w Polsce, a także wskazanie jego przyczyn i skutków.

PROBLEM I METODY BADAWCZE: Problem badawczy stawiany w niniejszej pracy jest następujący: czym charakteryzuje się zjawisko prawodemii w Polsce jako demokratycznym państwie prawnym, a także jakie były przyczyny oraz skutki jego występowania w dobie pandemii. Metoda badawcza polegała na analizie literatury z zakresu nauk społecznych, w tym w szczególności nauk socjologicznych, nauk o mediach i komunikacji społecznej oraz nauk prawnych.

PROCES WYWODU: Artykuł składa się z pięciu części. Pierwsza zawiera wstęp do rozważań zasadniczych i opisuje podłoże metodologiczne badań. W części drugiej podjęta została próba zdefiniowania prawodemii oraz omówienia jej cech charakterystycznych. W części trzeciej przeanalizowane zostały najważniejsze przyczyny tego zjawiska, a w części czwartej - najistotniejsze jego skutki. Ostatni fragment pracy stanowi podsumowanie zawierające wnioski naukowe.

WYNIKI ANALIZY NAUKOWEJ: Z przeprowadzonych analiz wynika, że w czasie trwania pandemii w Polsce doszło do niekorzystnego chaosu normatywnego wynikającego z nadmiaru regulacji prawnych i nazbyt dynamicznych ich zmian. Stan ten ujawniał się na trzech płaszczyznach: pierwotnej płaszczyźnie stanowienia prawa oraz dwóch płaszczyznach wtórnych - komunikacji o prawie oraz jego stosowania. Najważniejszymi przyczynami tak rozumianej prawodemii były: wzrost znaczenia funkcji dynamizującej, ochronnej oraz represyjnej prawa, a także wzrost znaczenia nieformalnych kanałów medialnych, za pośrednictwem których komunikowane były zmiany w prawie. Najważniejszym skutkiem prawodemii było natomiast zakłócenie świadomości prawnej społeczeństwa.

WNIOSKI, INNOWACJE, REKOMENDACJE: Innowacyjność badawcza artykułu polega na dostrzeżeniu nowego zjawiska społeczno-prawno-komunikacyjnego, jakim jest prawodemia. Pojęcie to stanowić może punkt wyjścia dla badań o charakterze empirycznym, w tym zwłaszcza dla badań dotyczących poziomu i zmian świadomości prawnej polskiego społeczeństwa oraz skuteczności nieformalnych kanałów przepływu informacji prawnej w dobie pandemii.

$\rightarrow$ SŁOWA KLUCZOWE: PRAWODEMIA, INFODEMIA, PRAWO, INFORMACJA PRAWNA, ŚWIADOMOŚĆ PRAWNA 


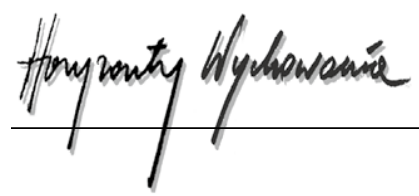

ABSTRACT

\section{Lawdemic, or the Legal Reality in the Era of the Pandemic in Poland}

RESEARCH OBJECTIVE: The scientific objective of this publication is to describe and justify the existence of the phenomenon of lawdemic in the era of pandemics in Poland, as well as to indicate its causes and effects.

THE RESEARCH PROBLEM AND METHODS: The research problem posed in this study is the following: what is the phenomenon of lawdemic in Poland as a democratic legal state, and what were the causes and consequences of its occurrence in the pandemic era. The research method consisted in the analysis of literature on social sciences, including in particular sociological sciences, sciences of media and social communication, and legal sciences.

THE PROCESS OF ARGUMENTATION: The article consists of five parts. The first one contains an introduction to the fundamental considerations and describes the methodological background of the research. In the second part, an attempt has been made to define lawdemic and to discuss its characteristics. In the third part, the most important causes of this phenomenon are analysed, and in the fourth part, the most significant effects of this phenomenon are presented. The last part of the paper is a summary with scientific conclusions.

RESEARCH RESULTS: The analyses show that during the pandemic in Poland there was an unfavourable normative chaos resulting from an excess of legal regulations and their overly dynamic changes. This state of affairs was manifested on three levels: the primary level of lawmaking and two secondary levels - communication about the law and its application. The most important causes of the lawdemic understood in this way were: the increase in the significance of the dynamising, protective and repressive functions of the law, as well as the increase in the significance of the informal media channels through which changes in the law were communicated. On the other hand, the most important effect of lawdemic was the disruption of legal awareness of the society.

CONCLUSIONS, INNOVATIONS, RECOMMENDATIONS: The research innovation of the article consists in the recognition of a new socio-legal-communication phenomenon, i.e. lawdemic. This concept can be a starting point for empirical research, especially research on the level and changes of legal awareness of the Polish society and the effectiveness of informal channels of legal information flow in the pandemic era.

$\rightarrow$ KEYWORDS: LAWDEMIC, INFODEMIC, LAW, LEGAL INFORMATION, LEGAL AWARENESS

\section{Wstęp}

Jak wskazuje Sławomir Doległo,

(...) trudno nie popaść w banał, opisując, jak pandemia SARS-CoV-2 zmieniła naszą codzienność. Od kilkunastu miesięcy kształtują ją epidemiczne statystyki, rządowe strategie 
obronne i sceny znane dotychczas za sprawą filmów katastroficznych i futurystycznych opowieści. Choć koronawirus wpłynął na nasze życie w wymiarze społecznym, ekonomicznym i politycznym, najbardziej odczuwamy to na poziomie osobistym i zawodowym (Doległo, 2021, s. 109).

Słowa te są bez wątpienia prawdą, jednak pomijają podstawową płaszczyznę dokonujących się zmian, a mianowicie płaszczyznę prawną. Wszelkie modyfikacje związane $z$ funkcjonowaniem państwa i jego obywateli w czasie zagrożenia epidemicznego posiadać bowiem muszą uzasadnienie normatywne. Wynika to $z$ treści art. 2 polskiej Konstytucji (1997), który stanowi, że „Rzeczpospolita Polska jest demokratycznym państwem prawym”. Przepis ten w sposób pośredni ustanawia regułę, w której „została (...) wyrażona wola, aby państwem zarządzano zgodnie z prawem, by prawo stało ponad państwem, było wytyczną działania dla niego i dla społeczeństwa" (Skrzydło, 2013, s. 34-35).

Sytuacja prawna w Polsce $\mathrm{w}$ dobie pandemii nie została dotychczas gruntowanie przeanalizowana przez naukowców, choć domaga się badania z perspektyw wielu nauk, w tym w szczególności nauk o komunikacji, prawa, socjologii, filozofii, a nawet językoznawstwa. Przyczynkiem do napisania niniejszego artykułu było zaobserwowanie nowego zjawiska, które dla potrzeb podejmowanych rozważań nazwane zostało przez autorkę mianem prawodemii. Nazwa ta przyjęta została na wzór infodemii, a więc terminu odnoszącego się do nieprawidłowości w przepływie informacji oraz szerzenia się zniekształconych, trudnych do zweryfikowania wiadomości - tzw. fake newsów (Penkala-Gawęcka, 2020). Pojęcie infodemii zostało po raz pierwszy użyte już w 2003 roku w odniesieniu do nadwyżki informacji związanych z pierwszą epidemią SARS (du Vall i Majorek, 2020). Kategoria prawodemii jest natomiast nowa i po raz pierwszy zostanie włączona do dyskursu naukowego w niniejszym artykule.

Zasadniczym celem podejmowanych rozważań jest uzasadnienie istnienia prawodemii, opisanie jej istoty, a także wskazanie najważniejszych przyczyn oraz skutków. Badania mają charakter teoretyczny i opierają się na analizie literatury z zakresu trzech nauk społecznych: nauk prawnych, nauk o mediach i komunikacji społecznej oraz nauk socjologicznych, w tym najnowszych opracowań dotyczących wpływu pandemii na całokształt życia społecznego. Autorka przyjęła interdyscyplinarny paradygmat myślowy, pragnąc uchwycić zjawisko prawodemii z różnych perspektyw życia społecznego. Przeprowadzone analizy stanowić mogą punkt odniesienia dla badań o charakterze empirycznym, w tym zwłaszcza dotyczących świadomości prawnej obywateli oraz skuteczności nieformalnych kanałów przepływu informacji prawnej w dobie pandemii.

\section{Kolejna „demia”, czyli czym jest prawodemia?}

Podejmując próbę zdefiniowania prawodemii, odwołać się należy do definicji infodemii przy jednoczesnym uwzględnieniu dzielących te zjawiska różnic. Zgodnie z poglądem wyrażonym przez Światową Organizację Zdrowia infodemia to: 


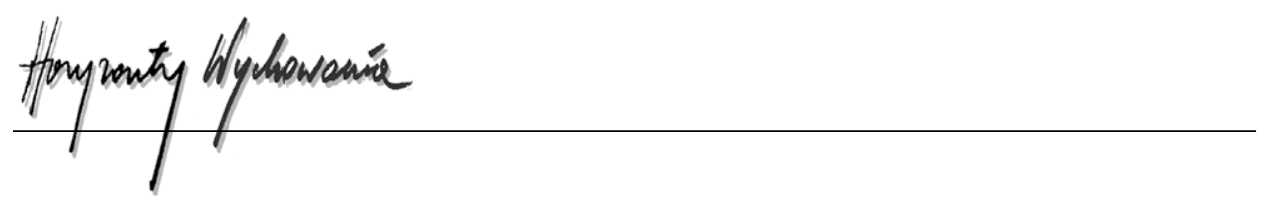

(...) szybkie rozprzestrzenianie informacji różnych rodzajów, z uwzględnieniem plotek, pogłosek i niewiarygodnych informacji. Są one upowszechniane natychmiast i na skalę międzynarodową dzięki popularności telefonów komórkowych, mediów społecznościowych, internetu i innych technologii służących do porozumiewania się (cyt. za: du Vall i Majorek, 2020, s. 179).

Okolicznością sprzyjającą rozwojowi infodemii jest więc z jednej strony powszechny dostęp do nowych technologii i mediów, a z drugiej - zaistnienie ważnych z perspektywy ogólnoludzkiej wydarzeń, wzmagających potrzebę komunikacji (Hodalska, 2018). Dążenie do realizacji tej potrzeby na szeroką skalę powoduje szumy komunikacyjne. Powstają one głównie na skutek jednoczesnego wyrażania prywatnych opinii, niepopartych oficjalnymi danymi ani wiedzą naukową, a także w wyniku zniekształceń w obrębie głównych kanałów przepływu informacji (Griffin, 2003). U uczestników komunikacji ujawniać się zaczyna stres informacyjny - tzw. info-stress (Ledzińska, 2002).

W oficjalnych deklaracjach Światowa Organizacja Zdrowia stwierdza, że infodemia związana z pandemią koronawirusa Sars-CoV-2 może realnie zagrażać zdrowiu ludzi przez zalecanie nieskutecznych, a nawet szkodliwych metod i środków leczniczych, a pośrednio przez potęgowanie atmosfery strachu, wywoływanie lęków, depresji i innych zaburzeń, a także chorób psychicznych (Wróblewski, 2020).

Podobnie jak infodemia, prawodemia odnosi się do nadmiaru i chaosu. Zakresy znaczeniowe tych dwóch terminów nie pokrywają się jednak. Po pierwsze, prawodemia dotyczy wyłącznie obszaru prawa, a więc przepisów stanowionych w przewidzianej formie przez uprawnione do tego władze państwowe. Po drugie, prawodemia wydaje się pojęciem szerszym od infodemii, bowiem obejmuje nie tylko proces komunikacji na temat prawa, ale również sferę jego tworzenia oraz stosowania. Prawodemia odnosi się zatem do szeroko rozumianego zamętu prawnego będącego konsekwencją wybuchu pandemii koronawirusa Sars-CoV-2 w Polsce. Termin ten nie powinien być odnoszony do zagranicznych porządków prawnych, bowiem ich funkcjonowanie w dobie zagrożenia epidemicznego nie było przedmiotem badań.

Pierwotną płaszczyzną rozwoju tak rozumianej prawodemii jest płaszczyzna stanowienia prawa. Obowiązująca Konstytucja Rzeczypospolitej Polskiej w sposób enumeratywny wymienia źródła prawa w art. 87 , zgodnie z którym

(...) źródłami powszechnie obowiązującego prawa Rzeczypospolitej Polskiej są: Konstytucja, ustawy, ratyfikowane umowy międzynarodowe oraz rozporządzenia; źródłami powszechnie obowiązującego prawa Rzeczypospolitej Polskiej są na obszarze działania organów, które je ustanowiły, akty prawa miejscowego (Konstytucja..., 1997, art. 87).

W czasie zagrożenia epidemicznego stanowienie prawa z konieczności przebiegać musiało w sposób dynamiczny, uwzględniający stopień rozwoju pandemii z jednej strony, a uwarunkowania społeczno-gospodarcze z drugiej. Bezzwłoczne wprowadzanie zmian w prawie możliwe było dzięki pomijaniu - w przypadkach prawnie dopuszczalnych - złożonego trybu ustawodawczego i wprowadzaniu nowych regulacji w drodze rozporządzeń Rady Ministrów, Prezesa Rady Ministrów oraz właściwych członków Rady 
Ministrów, w tym w szczególności Ministra Zdrowia. Stabilność prawa, stanowiąca jeden z podstawowych gwarantów jego społecznego autorytetu, została w wyniku tych procesów w znacznym stopniu zaburzona, a gwałtowna zmienność jego przepisów wzmagała w obywatelach poczucie zagrożenia (Kordela, 2012).

Nadmiar norm, które z konieczności odnosić się musiały do niemal każdej sfery życia prywatnego i publicznego, a także niespotykanie szybkie ich modyfikacje przyczyniły się do rozszerzenia zjawiska prawodemii na płaszczyznę komunikacji o prawie. Jednym z jego znamion było rozpowszechnianie fake newsów prawnych oraz innych deformacji informacji prawnych w ich nieformalnych kanałach przepływu. Pod pojęciem kanałów formalnych rozumiem, za Lechem Morawskim, przeznaczone do publikacji aktów prawnych oficjalne polskie dzienniki urzędowe: „Dziennik Ustaw Rzeczypospolitej Polskiej” oraz „Monitor Polski” (Morawski, 2004). Kanałami nieformalnymi są natomiast wszelkie inne źródła informacji prawnej dostępne dla obywateli. Z uwagi na fakt, że w praktyce są one wykorzystywane znacznie częściej niż kanały formalne (głownie ze względu na przystępność używanego języka) niezwykle ważne jest przekazywanie za ich pośrednictwem prawidłowej, niezniekształconej informacji na temat prawa. W dobie pandemii wiedza o normach prawnych czerpana była przede wszystkim z przekazów konferencji prasowych (przeważnie premiera i ministra zdrowia), z innych przekazów medialnych (w szczególności ze źródeł telewizyjnych i internetowych), a także z danych pozyskiwanych od innych osób. Dostęp do specjalistów z zakresu prawa, a tym samym możliwość uzyskania prawidłowej i jednolitej wykładni poszczególnych przepisów zostały istotnie ograniczone. Ograniczenia te dotyczyły zarówno prywatnych działalności prawniczych, jak i instytucji ukierunkowanych na niesienie bezpłatnej pomocy prawnej potrzebującym. Obywatele otrzymywali zatem niekompletną, bardzo często fałszywą informację prawną, której treść zniekształcona została poprzez bardzo silne szumy informacyjne.

Ostatnią płaszczyzną, na której doszło do ujawnienia się prawodemii, był obszar stosowania prawa. Stosowanie prawa rozumiem za Antonim Pieniążkiem oraz Małgorzatą Stefaniuk jako „czynienie przez jakiś podmiot użytku z kompetencji przyznanej mu przez normę prawną, zwaną z tego tytułu normą kompetencyjną" (Pieniążek i Stefaniuk, 2014, s. 256). W ujęciu takim za podmioty stosujące prawo uznawane są zarówno sądy, jak i sami obywatele - bezpośredni adresaci norm. Prawodemia objawiająca się nadmiarem norm i będąca wynikającym z tegoż nadmiaru zamętem prawnym doprowadziła do sytuacji, w której obywatele napotykali na trudności związane ze stosowaniem prawa (czy też lepiej: stosowaniem się do prawa), a sądy - z orzekaniem na jego podstawie. Problemy obywatelskie wynikały z zaburzeń komunikacji na temat prawa, przebiegającej przede wszystkim kanałami nieformalnymi. Brak pewności co do aktualnego stanu prawnego oraz szerzenie się prawnych fake newsów nierzadko uniemożliwiały dostosowanie zachowań do norm. W przypadku sądów informacja prawna dystrybuowana była natomiast poprzez kanały formalne. Trudności w stosowaniu prawa wynikały jednak z braku czasu na wykształcenie jednolitej wykładni przepisów oraz ich nierzadko wadliwej konstrukcji merytorycznej (nieostrości stosowanych pojęć, sprzeczności czy domniemanej niezgodności z przepisami wyższego rzędu). 


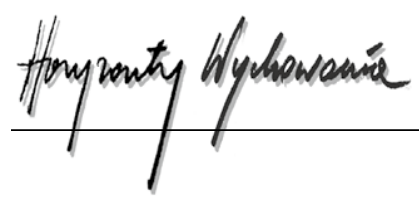

Podsumowując ten etap rozważań, podjąć należy próbę zdefiniowania prawodemii jako występującego w Polsce w dobie pandemii negatywnego zjawiska prawnego, społecznego i komunikacyjnego. Jego istotą jest chaos prawny wynikający z nadmiaru norm i nazbyt dynamicznych ich zmian, ujawniający się na trzech zasadniczych płaszczyznach: pierwotnej płaszczyźnie stanowienia prawa i dwóch płaszczyznach wtórnych komunikacji o prawie oraz jego stosowania. Rozważmy podstawowe przyczyny i skutki tej „nowo zdiagnozowanej choroby” polskiego porządku prawnego.

\section{Przyczyny prawodemii}

Jak się wydaje, za zasadniczą przyczynę prawodemii uznać należy zmianę najważniejszych funkcji pełnionych przez prawo w okresie pandemii w Polsce. W nauce prawa nie utrwalił się dotychczas jednolity pogląd na typologie funkcji spełnianych przez prawo, jednak badacze są zgodni co do tego, że funkcje takie da się wyodrębnić i opisać. Próbę stworzenia typologii podjęli między innymi Sławomira Wronkowska oraz Stanisław Ziembiński. Badacze ci wskazują, że ze względu na kierunek oddziaływania prawa wyróżnić można funkcję stabilizującą i dynamizującą, ze względu na rodzaj oddziaływania - funkcję ochronną i organizacyjną, a ze względu na sposób tegoż oddziaływania - funkcję represyjną i wychowawczą (Wronkowska i Ziembiński, 2001). Przybliżmy je pokrótce.

Funkcja stabilizująca prawa polega na utrwalaniu przez nie istniejącego ładu; istotą funkcji dynamizującej jest wprowadzanie zmian w poszczególnych obszarach życia społecznego. Funkcja ochronna wyraża się poprzez zapobieganie zachowaniom społecznie szkodliwym oraz nakłanianie obywateli do podejmowania działań ukierunkowanych na realizację przyjętych wartości. Jednym z aspektów tak rozumianej funkcji ochronnej prawa jest zatem aspekt prewencyjny. Z kolei funkcja organizacyjna przejawia się w koordynowaniu działań społecznych i stwarzaniu obywatelom możliwości podejmowania różnorodnych aktywności. Funkcja represyjna polega na pociąganiu obywateli do odpowiedzialności za czyny, zaś funkcja wychowawcza - na krewieniu postawy akceptowania prawa i jego przestrzegania bez uciekania się do kar czy działań o charakterze egzekucyjnym. Funkcje w ramach każdej pary powinny się znajdować względem siebie w równowadze, co zazwyczaj ma miejsce w normalnych warunkach funkcjonowania państwa i społeczeństwa (Wronkowska i Ziembiński, 2001). W demokratycznych państwach prawnych, do których należy Rzeczpospolita Polska, wskazać można nawet na niewielką przewagę funkcji stabilizującej nad dynamizującą, funkcji organizacyjnej nad ochronną oraz funkcji wychowawczej nad represyjną. Wynika to z dążenia władz do zachowania konstytucyjnych standardów przewidywalnej, stabilnej, szanującej przyrodzoną godność każdej istoty ludzkiej organizacji państwowej (Wronkowska i Ziembiński, 2001).

Wybuch pandemii koronawirusa Sars-CoV-2 oraz szybkie jego rozprzestrzenianie się uznać należy - pomimo niewprowadzenia przez rząd polski stanu nadzwyczajnego - za sytuację wyjątkową, wymagającą uruchomienia specjalnych metod i środków 
zaradczych, w tym w szczególności organizacyjnych i finansowych. W związku z tym zmianie uległy wzajemne relacje funkcji wypełnianych przez prawo. Funkcjami wiodącymi stały się funkcja dynamizująca, ochronna oraz represyjna. Pierwsza z nich ogniskowała się wokół szybkiego wykreowania nowych realiów codziennego funkcjonowania państwa i społeczeństwa niemal na każdej płaszczyźnie. Rozwiązania obowiązujące dotychczas uległy bowiem nagłej dezaktualizacji. Druga funkcja, ochronna, skupiała się roztoczeniu pieczy nad kluczowymi wartościami zagrożonymi na skutek pandemii - życiem i zdrowiem ludzkim, prawidłowym działaniem służby zdrowia, ciągłością działalności gospodarczej itd. Wzrost znaczenia funkcji represyjnej wynikał z kolei z konieczności zapewnienia przestrzegania nowo wprowadzanych norm w możliwie największym zakresie. Ranga ochranianych prawem wartości przyczyniła się tym samym do umniejszenia roli funkcji wychowawczej. Nacisk na realizację trzech omówionych funkcji wynikał z dążenia prawodawcy do sprostania trudnej rzeczywistości pandemicznej.

Kolejną przyczyną szerzenia się prawodemii w Polsce była ujawnienie się nowych nieformalnych kanałów przekazywania informacji prawnej. Należały do nich zwyczajowe konferencje prasowe, głównie Prezesa Rady Ministrów oraz Ministra Zdrowia (Świeca, 2020). Wiadomości na temat stanu prawnego czerpane były przez obywateli przede wszystkim ze środków masowego przekazu, w tym z internetu, za którego pośrednictwem wspomniane konferencje również były transmitowane (Świeca, 2020). Skutkowało to szybkim zniekształcaniem przekazywanych wiadomości i potęgowało zjawisko prawodemii w jego aspekcie komunikacyjnym. Często formułowane były fake newsy prawne, dotyczące zwłaszcza zakazów adresowanych do obywateli (w tym między innymi zakazu przemieszczania się, odwiedzania krewnych, cmentarzy, instytucji kultury itd.). Jak zostało już wspomniane, dostęp do specjalistycznej wiedzy prawniczej został w znacznym stopniu ograniczony, a wzmożony przepływ informacji prawnej drogą środków masowego przekazu oraz masowego komunikowania się na odległość charakteryzował się występowaniem wzmożonych szumów informacyjnych oraz brakiem precyzji w zakresie treści norm prawnych.

Przejdźmy w tym miejscu do omówienia najważniejszych skutków prawodemii w Polsce.

\section{Skutki prawodemii}

Zasadniczym, negatywnym skutkiem prawodemii jest zniekształcenie świadomości prawnej obywateli. Za Anną Gryniuk przyjmuję, że na świadomość prawą składają się trzy komponenty: znajomość prawa, jego ocena, a także przebierana wobec niego postawa (Gryniuk, 1979). Jak wskazują A. Pieniążek i M. Stefaniuk, „znajomość prawa pełni wśród elementów składających się na świadomość prawną rolę szczególną, gdyż warunkuje występowanie pozostałych" (Pieniążek i Stefaniuk, 2014, s. 169). Jak zostało już wielokrotnie zaznaczone, znajomość przepisów prawnych w dobie pandemii w Polsce bardzo często była zdeformowana. Obywatele, w większości będący przecież laikami, 


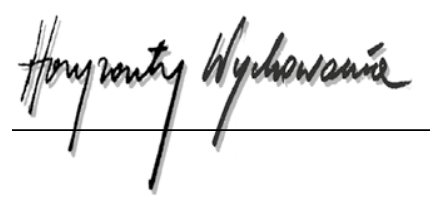

zmuszeni zostali do odnalezienia się w gąszczu nowo wprowadzanych, a następnie szybko derogowanych przepisów. Możliwość pogłębionej wykładni norm została zawężona, w tym także z powodu uwarunkowań czasowych, a w szczególności skrócenia bądź wyeliminowania okresu vacatio legis (Stefaniuk, 2016).

Dodać warto, że znajomość prawa obejmuje z jednej strony wiedzę na temat treści norm prawnych, a z drugiej - wiedzę o powodach ustanowienia tychże norm, o ich celach i rolach, jakie w założeniu prawodawcy mają do wypełnienia w świecie społecznym (Kojder, 2016). Dopiero współgranie ze sobą obu tych elementów kształtować może ocenę prawa oraz przybieraną względem niego postawę. Drugi aspekt znajomości prawa w dobie pandemii w Polsce także posiadał charakter powierzchowny. Adresaci norm musieli polegać głównie na interpretacjach formułowanych w mediach, które bardzo często posiadały wyraźne zabarwienie polityczne czy ideologiczne. Potęgowało to ogólny chaos informacyjny i stanowiło przeszkodę do odkodowania prawdziwych intencji prawodawcy.

Co oczywiste, znajomość prawa pośrednio warunkuje jego ocenę, a w konsekwencji - postawę, która, w uproszczeniu, może mieć charakter aprobujący bądź negujący. Pierwsza z nich skutkuje stosowaniem się do obowiązujących norm, zaś druga - celowym postępowaniem wbrew nim albo podejmowaniem prób ich ominięcia (Pieniążek i Stefaniuk, 2014). Teoretyczny model kształtowania się świadomości prawnej skonstruowany przez Marię Borucką-Arctową zakłada współwystępowanie w tym procesie następujących czynników: zmiennych struktury społecznej (cech związanych z przynależnością do poszczególnych grup społecznych, w szczególności warstw, klas i grup społeczno-zawodowych), zmiennych socjodemograficznych (wiek, płeć, stan rodzinny, miejsce zamieszkania, staż pracy itd.), uznawanych wartości i norm pozaprawnych, doświadczenia i dotychczasowych kontaktów z prawem, zmiennych sytuacyjnych oraz wpływu mediów (Borucka-Arctowa, 1980).

Zniekształcenia świadomości prawnej polskiego społeczeństwa w dobie pandemii wynikały przede wszystkim z dwóch z wymienionych czynników, a mianowicie ze zmiennych sytuacyjnych oraz z wpływu mediów. Omówmy je kolejno.

Zmienne sytuacyjne „można (...) definiować jako wszelkie niedające się enumeratywnie wymienić okoliczności, które w danym momencie mogą wpłynąć na świadomość prawną, a których nie da się w sposób wyczerpujący przewidzieć" (Pieniążek i Stefaniuk, 2014, s. 170).

Za okoliczność tego rodzaju bez wątpienia uznany może zostać wybuch pandemii koronawirusa Sars-CoV-2, który wymusił gwałtowne i radykalne przeobrażenia funkcjonowania państwa i społeczeństwa.

Wpływ mediów natomiast ,jest to niewątpliwie zmienna bardzo istotna, gdyż rozwój środków masowego przekazu w znaczący sposób wpłynął na świadomość prawną, stając się źródłem wiedzy o prawie i organach stosujących prawo" (Pieniążek i Stefaniuk 2014, s. 171).

Do chwili wybuchu pandemii nigdy dotychczas w historii Polski zakres informacji prawnej przekazywanej za pośrednictwem mediów nie był tak znaczący, dynamiczny 
i szeroko dyskutowany zarówno w dyskursie publicznym, jak i prywatnym. Wymienione czynniki kształtowania świadomości prawnej społeczeństwa skutkowały zaburzeniami ocen i postaw wobec prawa. Formułowane oceny bardzo często miały charakter emocjonalny, a przejawiane postawy - opozycyjny względem ustanowionych przepisów. Zauważyć warto, że podłożem zaburzeń ocen i postaw był także chaos orzeczniczy, wynikający z rozbieżności w stosowaniu prawa przez sądy.

Podsumowując, dostrzeżone dysfunkcje społecznej świadomości prawnej były bez wątpienia najpoważniejszym, jednoznacznie negatywnym skutkiem prawodemii w Polsce. Przejawiały się w postawach oportunistycznych i nonkonformistycznych, w podejmowaniu starań o obejście prawa bądź uniknięcie ujemnych skutków zachowań z nim niezgodnych.

\section{Wnioski}

Z przeprowadzonych analiz wynika, że w czasie trwania pandemii w Polsce doszło do niekorzystnego chaosu normatywnego wynikającego z nadmiaru regulacji prawnych i nazbyt dynamicznych ich zmian. Stan ten ujawniał się na trzech płaszczyznach: pierwotnej płaszczyźnie stanowienia prawa oraz dwóch płaszczyznach wtórnych - komunikacji o prawie oraz jego stosowania. Najważniejszymi przyczynami tak rozumianej prawodemii były: wzrost znaczenia funkcji dynamizującej, ochronnej oraz represyjnej prawa, a także wzrost znaczenia nieformalnych kanałów medialnych, za których pośrednictwem komunikowane były zmiany w prawie. Najważniejszym skutkiem prawodemii było natomiast zakłócenie świadomości prawnej społeczeństwa.

Pojęcie prawodemii stanowić może punkt wyjścia dla badań o charakterze empirycznym, w tym zwłaszcza dla badań dotyczących poziomu i zmian świadomości prawnej polskiego społeczeństwa oraz skuteczności nieformalnych kanałów przepływu informacji prawnej w dobie pandemii. Z uwagi na fakt, że postawy wobec prawa najczęściej posiadają charakter względnie trwałych dyspozycji, możliwe jest, że po zakończeniu pandemii nieufność wobec przepisów, a także jawny względem niech opór nadal będą demonstrowane przez tych obywateli, którzy przejawiali je w okresie pandemii.

\section{BIBLIOGRAFIA}

Borucka-Arctowa, M. (1980). Świadomość prawna społeczeństwa polskiego. Ruch Prawniczy, Ekonomiczny i Socjologiczny, 152(1), 153-165.

Doległo, S. (2021). Infodemia koronawirusa. Medialny obraz pandemii oczami młodych badaczy. Zeszyty Prawoznawcze, 64(1), 109-112.

du Vall, M. i Majorek, M. (2020). Zarządzanie informacją przez instytucje publiczne - studium przypadku komunikacji kryzysowej Ministerstwa Zdrowia via Twitter w okresie pandemii. Bezpieczeństwo. Teoria i Praktyka, 4, 175-197. 


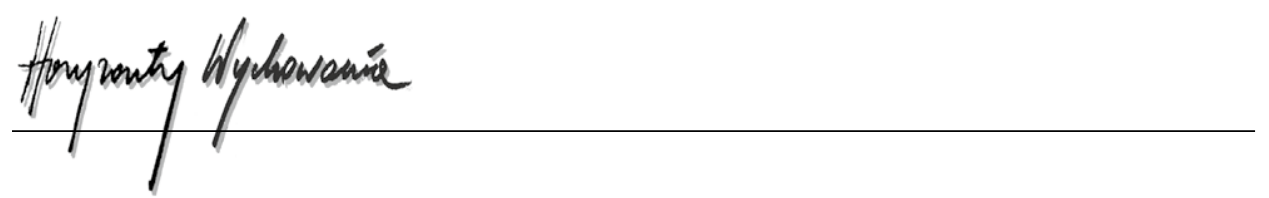

Griffin, E.A. (2003). Podstawy komunikacji społecznej (O. i W. Kubińscy i M. Kacmajor, tłum). Gdańsk: Gdańskie Wydawnictwo Psychologiczne.

Gryniuk, A. (1979). Świadomość prawna. Studium teoretyczne. Toruń: Wydawnictwo Uniwersytetu Mikołaja Kopernika.

Hodalska, M. (2018). Nadciąga zagłada! Retoryka strachu w polskich mediach na przykładzie prasowych relacji z epidemii ptasiej i świńskiej grypy. Kultura - Media - Teologia, 32(1), 25-40.

Kojder, A. (2016). Podstawy socjologii prawa. Warszawa: Oficyna Naukowa.

Konstytucja Rzeczypospolitej Polskiej z dnia 2 kwietnia 1997 roku. Dz.U. Nr 78, poz. 483 z późn. zm. (Polska).

Kordela, M. (2012). Zasady prawa. Studium teoretycznoprawne. Poznań: Wydawnictwo Uniwersytetu Adama Mickiewicza.

Morawski, L. (2004). Wstęp do prawoznawstwa. Toruń: Wydawnictwo „Dom Organizatora”.

Ledzińska, M. (2002). Stres informacyjny jako zagrożenie dla rozwoju. Roczniki Psychologiczne, $5,77-97$.

Penkala-Gawęcka D. (2020). Covid-19, niepewność, lęk i nadzieja. W poszukiwaniu skutecznego leku. Lud, 104, 185-212.

Pieniążek, A. i Stefaniuk, M. (2014). Socjologia prawa. Zarys wykładu. Warszawa: Wydawnictwo Wolters Kluwer.

Skrzydło, W. (2013). Konstytucja Rzeczypospolitej Polskiej. Komentarz. Warszawa: Wydawnictwo Wolters Kluwer.

Stefaniuk, M. (2016). Zasada odpowiedniego vacatio legis jako element ochrony zaufania obywateli do państwa i stanowionego przez nie prawa. Studia luridica Lublinensia, 25(1), 59-75.

Świeca, L. (2020). Makiawelizm medyczny: medialna dezinformacja w sprawie maseczek chroniących przed koronawirusem w Polsce. W: K. Marcinkiewicz, P. Nowak, D. Popielec i M. Wilk (red.), Koronawirus wyzwaniem współczesnego społeczeństwa : media i komunikacja społeczna. Kraków: Wydawnictwo Uniwersytetu Jagiellońskiego.

Wronkowska, S. i Ziembiński, Z. (2001). Zarys teorii prawa. Poznań: Przedsiębiorstwo Wydawnicze Ars Boni Et Aequi.

Wróblewski, M. (2020). Superroznosiciele wątpliwości. Sceptycyzm i teorie spisowe w dobie koronawirusa. Dyskurs i Dialog, 4, 23-35.

\section{Copyright and License}

This article is published under the terms of the Creative Commons Attribution - NoDerivs (CC BY- ND 4.0) License http://creativecommons.org/licenses/by-nd/4.0/ 